\title{
New Insights into the Chemistry of cis-Dioxomolybdenum(VI) Schiff Base Complexes with Macrocyclic Ligands
}

\author{
RAMESH KUMAR GAUTAM ${ }^{1 *}$, CHANDRA PRAKASH SINGH ${ }^{2}$, \\ DINESH KUMAR ${ }^{3}$ and DEVENDRA PRATAP RAO ${ }^{1}$
}

${ }^{1}$ Department of Chemistry, D.A.V. (P.G.) College, Kanpur-208001, U.P., India

${ }^{2}$ Department of Chemistry, D.B.S. (P.G.) College, Kanpur-208006, U.P., India

${ }^{3}$ Department of Chemistry, Bipin Bihari College, Jhansi, U.P., India

devendraprataprao@yahoo.com

Received 24 May 2019 / Accepted 2 July 2019

\begin{abstract}
Preparation of one parent dioxomolybdenum(VI) complex of formula $\left[\mathrm{MoO}_{2}(\mathrm{~L})\right](\mathrm{acac})_{2}$ with a Schiff base, obtained from condensation of thenil with 2,3-diamino-5-chloropyridine and four new complexes having formula $\left[\mathrm{MoO}_{2}(\mathrm{ML})\right](\mathrm{acac})_{2}$, derived from cyclization of $\left[\mathrm{MoO}_{2}(\mathrm{~L})\right](\mathrm{acac})_{2}$ with $\beta$-diketones are reported in this research paper. The prepared five dioxomolybdenum(VI) complexes have been described by elemental analyses, molar conductance, UV-Vis, IR, NMR and thermal studies. The feasibility of coordination number of molybdenum metal is six. All five complexes of dioxomolybdenum(VI) have octahedral geometry. The octahedral coordination circle of molybdenum in synthesized dioxomolybdenum complexes is completed by two oxo oxygen atoms and four nitrogen atoms from derived ligand. The shape of synthesized dioxomolybdenum(VI) complexes have distorted octahedral. All the synthesized complexes showed moderate activity against S. aureus and S. typhi, the improvement in the antibacterial activity being explained on the basis of chelation hypothesis.
\end{abstract}

Keywords: Dioxomolybdenum(VI), Thenil, $\beta$-Diketones, Macrocyclic complexes, Schiff base

\section{Introduction}

A macrocyclic complex is characterized as a cyclic complex with at least nine individuals (counting all hetero atoms) and with at least three donor atoms. The field of coordination chemistry of macrocyclic complexes has experienced dynamite development amid the previous quarter century ${ }^{1-4}$. Schiff bases assume a significant job in chemistry as they effectively structure stable edifices with most transition metal ion. Schiff base complexes edifices may serious as models for biologically significant species. Severe research efforts have been governed to study the transition metal complexes of high denticity ligands with a 
view to obtain the metal complexes of unusual configuration and coordination number ${ }^{5}$. Molybdenum is adaptable in nature due to its various oxidation states ranging from -2 to +6 just as coordination numbers which fluctuate from four to eight ${ }^{6}$. The capacity to arrangement of molybdenum buildings with nitrogen, oxygen and sulfur containing ligands prompted improvement of molybdenum Schiff base edifices which are productive impetuses in homogeneous and furthermore in heterogeneous reactions ${ }^{7-12}$. The dioxomolybdenum(VI) complexes with denticity ligands have extraordinary significance in theoretical and practical area especially for biological processes. $\mathrm{Mo}(\mathrm{VI})$ is available as a simple molybdate $\left[\mathrm{MoO}_{4}\right]^{2-}$ ion in aqueous medium be dependent on the concentration and $\mathrm{pH}$ of the solution. The $\left[\mathrm{MoO}_{4}\right]^{2-}$ ion can perform as oxygen atom transfer agents ${ }^{13}$. Their oxygen atom transfer properties play a vital role within functioning mechanism of molybdenum oxotransferase ${ }^{14,15}$. It is significant in the totally oxidized states of a number of redox enzymes, in which their active sites consists of a cis-dioxomolybdenum moiety ${ }^{16-18}$.

In the second series of transition metals, solely molybdenum is into account as biometal which is important for human, animal and plants pathogenic microorganisms ${ }^{19,20}$. The coordination chemistry of $\mathrm{Mo}(\mathrm{VI})$ is an effectively interest of present research because of their catalytic properties and biological activities ${ }^{21-24}$. Physiological functions of oxomolybdoenzymes are established by molybdenum ${ }^{25-27}$. Thenil could be a versatile chelating agent. Thenil has two reactive carbonyl groups which are capable of undergoing Schiff base condensation with several di- and polyamines. Therefore, thenil has played a vital role within the synthesis of macrocyclic ligands.

With on top of context, some dioxomolybdenum(VI) complexes with high denticity ligands can synthesize from condensation of thenil with diamine. The synthesized complex has capability of undergoing cyclization with $\beta$-diketones via the metal template effect will be prepare, characterize and their provisional structures are supported by molar conductivity, elemental analysis, electronic, infra red and nuclear magnetic resonance spectroscopy. A large number of metallic complexes of obviously occurring porphyrins, corrins and phthalocyanines were investigated, due to their relation to important naturally occurring macrocycles together with heam. Cytochromes or chlorophyll, because of their ability as dyestuffs pigments. The extent of interest in such complexes may be imagined.

Keeping in view of the significance of dioxomolybdenum(VI) cations in oxygen transfer reactions, a new sequence of dioxomolybdenum(VI) macrocyclic complexes have been synthesized. These dioxomolybdenum(VI) macrocyclic complexes with new chelate ligands got from condensation of thenil with 2,3-diamino-5-chloropyridine capable to undergoing cyclization with $\beta$-diketones through the metallic template effect have been synthesized. Herein, the synthesis and their ascertain structures, based on molar conductivity, elemental analyses, electronic IR, NMR and TGA/DTA are reported.

\section{Experimental}

All chemicals used for the synthesis of Schiff base (ligands) and complexes had been of reagent grade and employed as purchased from commercial assets. Molybdenyl acetylacetonate, 2,3-diamino-5-chloropyridine, thenil and $\beta$-diketones (acetylacetone, benzoylacetone, thenoyltrifluoroacetone and dibenzoylmethane) had been purchased from Aldrich and employed without similarly purification.

\section{Analytical methods and physical measurements}

Elemental analyses of carbon, hydrogen and nitrogen for the complexes had been done at valuable Central Research Facility, NERIST, Nirjuli, Itanagar, Arunachal Pradesh, India by 
using CHN analyser. Kjeldahl's method becomes used to estimate nitrogen for the prepared complexes. After decomposition of the complex, molybdenum was estimated gravimetrically via standard method ${ }^{28}$. Estimation of sulfur became achieved as barium sulfate $^{29}$. General method changed into used for determining uncorrected melting factors with the help of sulfuric acid bath. The electronic absorption spectral measurements (the UV-Visible spectra) of the complexes had been recorded on Labinda-UV $3000^{+}$UV/VIS spectrophotometer within the ranges $1100-220 \mathrm{~nm}$ by using ethanol as solvent at UPTTI Kanpur, U.P., India. The IR of the synthesized dioxomolybdenum complexes (4000-400 $\mathrm{cm}^{-1}$ ) were recorded in $\mathrm{KBr}$ on Perkin-Elmer spectrum model 10.03.06 spectrophotometers at IIT Kanpur. NMR spectra have been acquired on JMM ECS-400 (JEOL) spectrometer with $400 \mathrm{MHz}$ for proton $\left({ }^{1} \mathrm{H}\right.$ NMR). Thermograph of the prepared parent complex $\left[\mathrm{MoO}_{2}(\mathrm{~L})\right](\mathrm{acac})_{2}$ was done under nitrogen atmosphere in the temperature range $50-600{ }^{\circ} \mathrm{C}$ at the heating rate $10{ }^{\circ} \mathrm{C} \mathrm{min}{ }^{-1}$ using TG/DTA-Perkin Elmer, USA thermal analyzers.

In-situ synthesis of dioxomolybdenum(VI) complexes with ligands derived by condensation of thenil with 2,3-diamino-5-chloropyridine with $\beta$-diketones

Given Scheme 1 shows the procedure manner of $\left[\mathrm{MoO}_{2}(\mathrm{ML})\right](\mathrm{acac})_{2}$. An ethanolic solution of molybdenyl acetylacetonate $(2.5 \mathrm{mmol}, 0.81537 \mathrm{~g})$ was added drop wise to a refluxing solution of thenil (2.5 mmol, $0.5570 \mathrm{~g}$ ) and 2,3-diamino-5-chloropyridine (5 mmol, $0.71785 \mathrm{~g}$ ) in ethanol $(50 \mathrm{~mL})$ in $\mathrm{RB}$ flask. The resulting reaction mixture turned into mild refluxed for $2 \mathrm{~h}$. The coloration of the mixture turned into brown. The obtained solid product was filtered off, washed with ethanol and isolated under in vacuo over silica gel. Purity of the complex checked through TLC. The yield became $46 \%$ (type I).
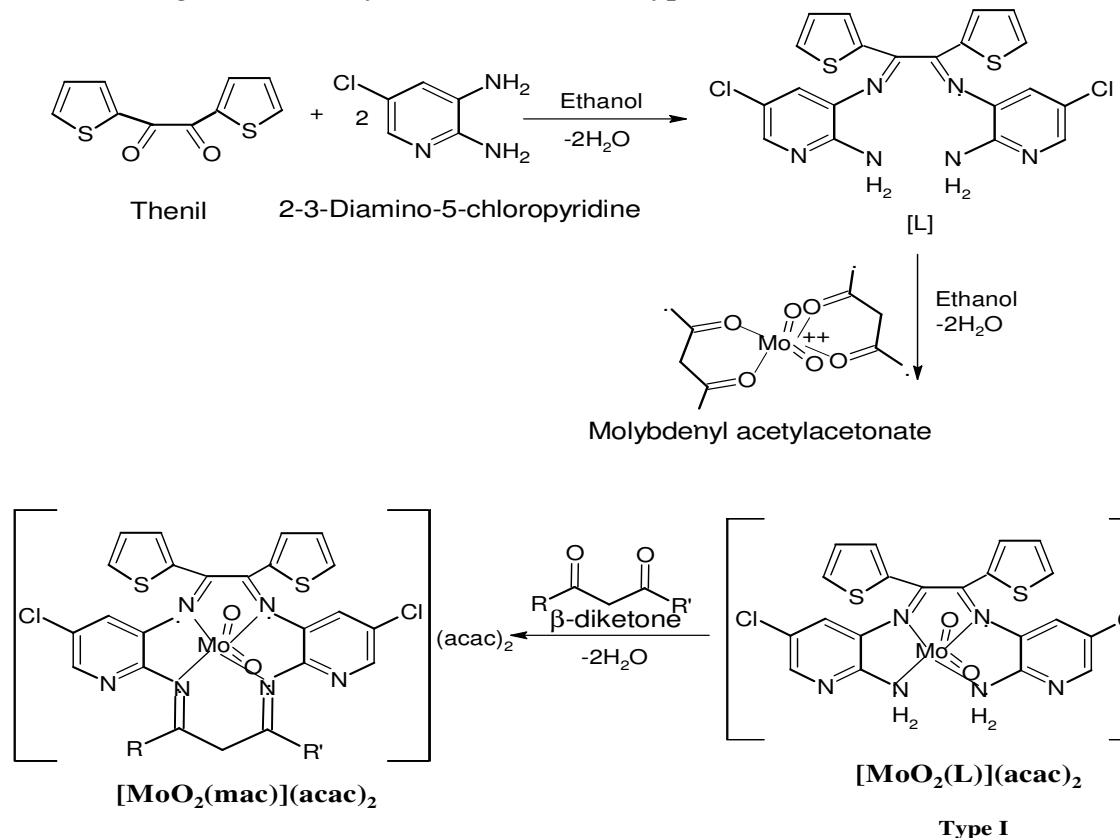

Type II

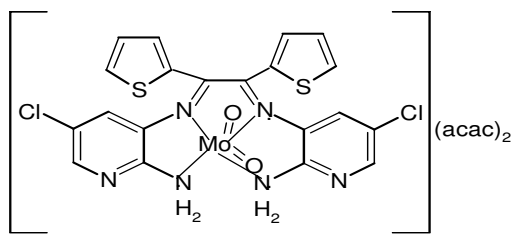

$\left[\mathrm{MoO}_{2}(\mathrm{~L})\right](\mathbf{a c a c})_{2}$

Type I

Where, $\mathrm{L}=$ Thenil +2,3-diamino-5-chloropridine; mac = macrocyclic ligands carried out from condensation of $\mathrm{L}$ with $\beta$-diketones in presence of dioxmolybdenum(VI) cation

Scheme 1. Synthesis of $\left[\mathrm{MoO}_{2}(\mathrm{~L})\right](\mathrm{acac})_{2}$ and of $\left[\mathrm{MoO}_{2}(\mathrm{mac})\right](\mathrm{acac})_{2}$ 
The solution of type I suspended in ethyl alcohol uniformly reacted for $2 \mathrm{~h}$ with $\beta$-diketones viz., acetylacetone, benzoylacetone, thenoyltrifluoroacetone or dibenzolylmethane (1:1) to obtain macrocyclic solid products (type II). The purity of the macrocyclic complexes becomes checked by means of TLC. Elemental analyses (Table $1 \& 2$ ) of the complexes exhibited 1:1 metal to ligand stoichiometry.

Table 1. Physical and analytical data of the ligand and complexes

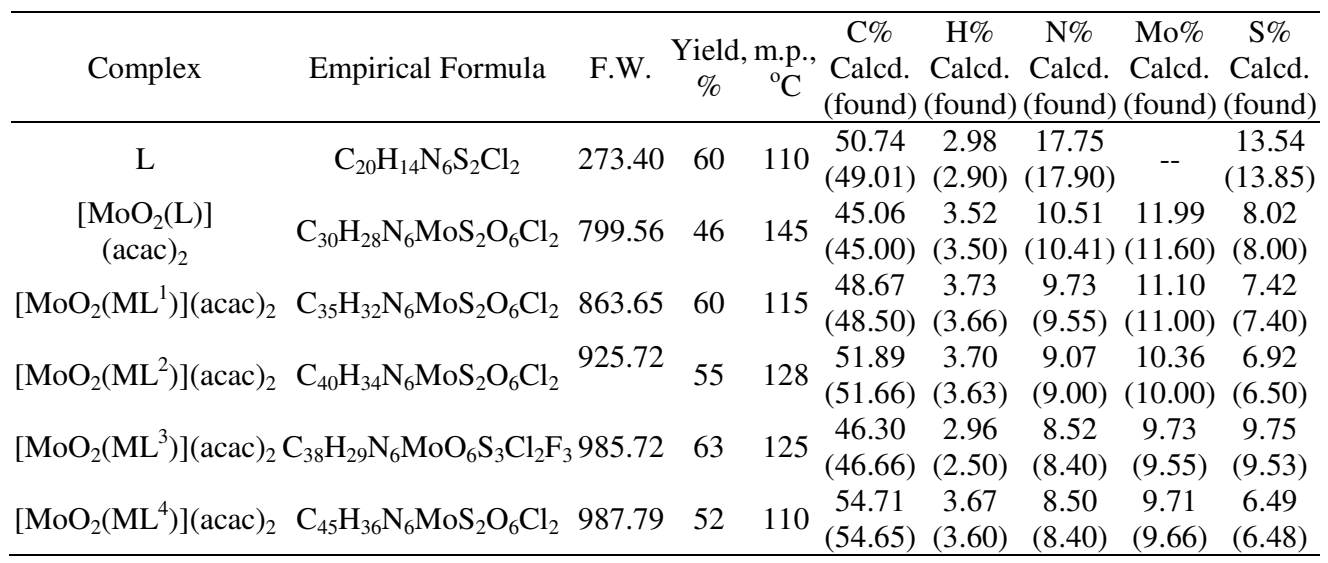

Table 2. Structural details

\begin{tabular}{ccccc}
\hline For macrocyclic & $\mathrm{R}$ & $\mathrm{R}^{\prime}$ & $\beta$-diketone & acetylacetone \\
$\mathrm{ML}^{1}$ & $\mathrm{CH}_{3}$ & $\mathrm{CH}_{3}$ & benzoylacetone \\
$\mathrm{ML}^{2}$ & $\mathrm{C}_{6} \mathrm{H}_{5}$ & $\mathrm{CH}_{3}$ & thenoyltrifluoroacetone \\
$\mathrm{ML}^{3}$ & $\mathrm{C}_{4} \mathrm{H}_{3} \mathrm{~S}$ & $\mathrm{CF}_{3}$ & dibenzoylmethane \\
$\mathrm{ML}^{4}$ & $\mathrm{C}_{6} \mathrm{H}_{5}$ & $\mathrm{C}_{6} \mathrm{H}_{5}$ & Structure \\
\hline
\end{tabular}

Where, $\mathrm{L}=$ ligand obtained by condensation of thenil with 2,3-diamino-5-chloropyridine (1:2);

$\mathrm{ML}^{1}=$ macrocyclic ligand obtained by condensation of ligand $(\mathrm{L})$ with $\beta$-diketone-acetylacetone;

$\mathrm{ML}^{2}=$ macrocyclic ligand obtained by condensation of ligand $(\mathrm{L})$ with $\beta$-diketone-benzoylacetone;

$\mathrm{ML}^{3}=$ macrocyclic ligand obtained by condensation of ligand $(\mathrm{L})$ with $\beta$-diketone-thenoyltrifluoroacetone;

$\mathrm{ML}^{4}=$ macrocyclic ligand obtained by condensation of ligand (L) with $\beta$-diketone-dibenzoylmethane.

Antibacterial activity assay

The antibacterial interest of the synthesized dioxomolybdenum(VI) complexes have been evaluated in vitro against four bacterial strains i.e. Staphylococcus aureus, Bacillus subtilis, Enterobacter aerogene and Salmonella typhi using cup and agar-well diffusion method ${ }^{20-22}$. Doxycycline was used as the same standard antibacterial agent. Wells having size of $6 \mathrm{~mm}$ in diameter had been dug in the agar media with the help of metallic borer. The density of every bacterial suspension in each well changed into adjusted to $3 \times 10^{5}$ colony-forming units (CFU) $\mathrm{mL}^{-1}$. The standardized suspensions had been spread on the surface of the agar. The synthesized complexes were dissolved in $1 \%$ DMSO and concentration of the check sample was $300 \mu \mathrm{g} \mathrm{mL}^{-1}$. The test samples were introduced inside the corresponding wells. Other wells 
had been packed with DMSO and antibacterial agent doxycycline $(0.05 \%)$. Growth inhibition was examined after $28 \mathrm{~h}$ incubation at $35^{\circ} \mathrm{C}$.

\section{Results and Discussion}

\section{Infrared spectra}

The complexes of dioxomolybdeum(VI) with Schiff base were prepared by the use of an in-situ method by refluxing the reaction mixture of thenil, 2,3-diamino-5-chloropyridine and molybdenyl acetylacetonate in 1:2:1 molar ratio in aqueous ethanol which result in macrocyclic complexes according to scheme. Significant IR spectral bands of the ligand and the dioxomolybdenum(VI) and their tentative assignments are given in Table 3. The coordination of nitrogen atoms of azomethine groups to the molybdenum in all macrocyclic complexes have been evidenced by using the shift of $v_{\mathrm{C}=\mathrm{N}}$ to decrease frequencies $\mathrm{s}^{30-33}$. The spectral bands region $1651-1655 \mathrm{~cm}^{-1}$ is associated with $>\mathrm{C}=\mathrm{N}$ absorption, which normally appears at $1675 \mathrm{~cm}^{-1}$ in isolated ligands ${ }^{30-32}$. New absorption band at around $456-475 \mathrm{~cm}^{-1}$ can be assigned to $v_{\text {Mo-N }}$ vibration $^{34}$, that is absent in free ligands. The coordination of two keto groups of thenil via carbonyl oxygen with diamines was supported ${ }^{35-36}$ via the appearance of $>\mathrm{C}=\mathrm{N}$ band and the absence of the $>\mathrm{C}=\mathrm{O}$ band around $1710 \mathrm{~cm}^{-1}$. Infra red spectra of the ligand and its complexes of dioxomolybdeum(VI) are complicated due to the presence of various ring vibrations and $\mathrm{C}-\mathrm{H}$ vibrations. A broad band targeted at $3350 \mathrm{~cm}^{-1}$ for $v_{\text {asym }(\mathrm{N}-\mathrm{H})}$ and $3190 \mathrm{~cm}^{-1}$ for $v_{\mathrm{sym}(\mathrm{N}-\mathrm{H})}$. In the complex $\left[\mathrm{MoO}_{2}(\mathrm{~L})\right](\mathrm{acac})_{2}$ bands stay unchanged however absent in complex $\left[\mathrm{MoO}_{2}(\mathrm{ML})\right](\mathrm{acac})_{2}$ due to the this implies non-participation of the $\mathrm{NH}$ group in the bonding ${ }^{37}$. The dioxomolybdenum(VI) complexes to create preferentially a cis-dioxo group due to the most utilization of the d-orbital for bonding. The dioxomolybdenum(VI) complexes showed two $\mathrm{Mo}=\mathrm{O}$ stretching bands at $903-910 \mathrm{~cm}^{-1}$ and $930-946 \mathrm{~cm}^{-1}$ because of two stretching vibrations: asymmetric and symmetric stretching of the cis- $\left[\mathrm{MoO}_{2}\right]^{2+}$ moiety in $\mathrm{C}_{2 \mathrm{~V}}$ symmetry ${ }^{38}$. Those two infrared spectral bands are assigned to $v_{\text {asym }(\mathrm{O}=\mathrm{Mo}=\mathrm{O})}$ and $\mathrm{v}_{\mathrm{sym}(\mathrm{O}=\mathrm{Mo}=\mathrm{O})}$ vibrations respectively ${ }^{38-44}$. $\mathrm{N}_{\text {asym }}(\mathrm{O}=\mathrm{Mo}=\mathrm{O})$ vibrations are lesser than those of $\mathrm{v}_{\mathrm{sym}}(\mathrm{O}=\mathrm{Mo}=\mathrm{O})^{45,46}$. The presence of acetylacetonate group present in outer coordination sphere is affirmed by the bands appearing around $1540-1565 \mathrm{~cm}^{-1}$ and $1465-1485 \mathrm{~cm}^{-1}$ are appointed to $v_{\mathrm{C}=\mathrm{O}}$ and $v_{\mathrm{C}=\mathrm{C}}$ vibrations ${ }^{47}$. Infrared spectral bands of the macrocyclic complexes display the same pattern of spectral bands. The asymmetrical and symmetrical N-H stretching modes of terminal amino groups disappear as a result of coordination of those amino groups with carbonyl group of $\beta$-diketones in cyclization processes $^{47,48}$.

Table 3 Infrared spectral bands $\left(v / \mathrm{cm}^{-1}\right)$ of molybdenum complexes. All spectra had been recorded using $\mathrm{KBr}$ within the range $4000-400 \mathrm{~cm}^{-1}$

\begin{tabular}{ccccccccc}
\hline Complex & $v_{\mathrm{C}=\mathrm{N}}$ & $v_{\mathrm{Mo}-\mathrm{N}}$ & $\begin{array}{c}v_{\mathrm{C}=\mathrm{O}} \text { of } \\
\text { acetylacetonate acetylacetonate }\end{array}$ & $\begin{array}{c}v_{\mathrm{C}=\mathrm{C}=\mathrm{M}=\mathrm{O})}(\mathrm{O}=\mathrm{M} \mathrm{M}=\mathrm{O}) \\
\text { asym }\end{array}$ & $\begin{array}{c}v_{\text {asym }} \\
(\mathrm{N}-\mathrm{H})\end{array}$ & $\begin{array}{c}v_{\text {sym }} \\
(\mathrm{N}-\mathrm{H})\end{array}$ \\
\hline $\mathrm{L}$ & $1675 \mathrm{~s}$ & - & - & - & - & - & $3350 \mathrm{br} 3190 \mathrm{br}$ \\
{$\left[\mathrm{MoO}_{2}(\mathrm{~L})\right](\mathrm{acac})_{2}$} & $1651 \mathrm{~s}$ & $473 \mathrm{~m}$ & $1540 \mathrm{~s}$ & $1485 \mathrm{~m}$ & $910 \mathrm{~s}$ & $936 \mathrm{~s}$ & $3338 \mathrm{br} 3167 \mathrm{br}$ \\
{$\left[\mathrm{MoO}_{2}\left(\mathrm{ML}^{1}\right)\right](\mathrm{acac})_{2}$} & $1655 \mathrm{~s}$ & $469 \mathrm{~s}$ & $1565 \mathrm{~m}$ & $1472 \mathrm{~m}$ & $905 \mathrm{~s}$ & $930 \mathrm{~s}$ & \\
{$\left[\mathrm{MoO}_{2}\left(\mathrm{ML}^{2}\right)\right](\mathrm{acac})_{2}$} & $1650 \mathrm{~s}$ & $465 \mathrm{~m}$ & $1559 \mathrm{~s}$ & $1465 \mathrm{~m}$ & $900 \mathrm{~s}$ & $940 \mathrm{~s}$ & \\
{$\left[\mathrm{MoO}_{2}\left(\mathrm{ML}^{3}\right)\right](\mathrm{acac})_{2}$} & $1646 \mathrm{~s}$ & $475 \mathrm{~m}$ & $1545 \mathrm{~s}$ & $1470 \mathrm{~m}$ & $905 \mathrm{~m}$ & $938 \mathrm{~m}$ & \\
{$\left[\mathrm{MoO}_{2}\left(\mathrm{ML}^{4}\right)\right](\mathrm{acac})_{2}$} & $1648 \mathrm{~m}$ & $456 \mathrm{~m}$ & $1560 \mathrm{~m}$ & $1480 \mathrm{~m}$ & $903 \mathrm{~m}$ & $946 \mathrm{~s}$ & \\
\hline
\end{tabular}

\section{${ }^{1} H$ NMR spectra}

${ }^{1} \mathrm{H}$ NMR spectra of ligand and all synthesized molybdenum complexes had been recorded in DMSO-D 6 (Table 4). ${ }^{1} \mathrm{H}$ NMR spectrum of synthesized free ligand suggests signal because of $\mathrm{NH}_{2}$ at $\delta(10.22)$ which is also present in $\left[\mathrm{MoO}_{2}(\mathrm{~L})\right](\mathrm{acac})_{2}$ at $\delta(10.09)$ but absent in different 
four macrocyclic complexes $\left[\mathrm{MoO}_{2}(\mathrm{ML})\right](\mathrm{acac})_{2}$ which suggest the cyclization by $\beta$ diketones. The ten protons present as multiplets within the range $\delta(6.60-7.26)$ for the ligand and molybdenum complexes. The protons of aromatic ring showed by peaks around $\delta$ (7.26). ${ }^{1} \mathrm{H}$ NMR spectrum around $\delta$ (3.5-4.6) assigned to the $\mathrm{CH}_{2} \mathrm{~N}$ fragment. The appearance of these chemical shifts may be because of the formation of two types of azomethine that is involved in the formation of the macrocyclic complex. The sharp singlet signal located at $\delta$ (2.36) may be due to the water present in $\mathrm{DMSO}-\mathrm{D}_{6}$ sample used.

Table 4. ${ }^{1} \mathrm{H}$ NMR spectral data of prepared ligand and dioxomolybdenum complexes (in $\delta$ )

\begin{tabular}{ccccc}
\hline Complex & $\mathrm{HC}-\mathrm{Ar}$ & $\mathrm{N}-\mathrm{H}$ & $\mathrm{C}-\mathrm{H}_{3}$ & $\mathrm{C}-\mathrm{H}$ \\
\hline $\mathrm{L}$ & $7.1210 \mathrm{H}$ & $10.224 \mathrm{H}$ & - & - \\
{$\left[\mathrm{MoO}_{2}(\mathrm{~L})\right](\mathrm{acac})_{2}$} & $6.5810 \mathrm{H}$ & $10.094 \mathrm{H}$ & $2.5612 \mathrm{H}$ & $5.652 \mathrm{H}$ \\
{$\left[\mathrm{MoO}_{2}(\mathrm{ML})\right](\mathrm{acac})_{2}$} & $7.2610 \mathrm{H}$ & - & $2.6212 \mathrm{H}$ & $5.572 \mathrm{H}$ \\
{$\left[\mathrm{MoO}_{2}\left(\mathrm{ML}^{2}\right)\right](\mathrm{acac})_{2}$} & $7.1510 \mathrm{H}$ & - & $2.5512 \mathrm{H}$ & $5.682 \mathrm{H}$ \\
{$\left[\mathrm{MoO}_{2}\left(\mathrm{ML}^{3}\right)\right](\mathrm{acac})_{2}$} & $6.6010 \mathrm{H}$ & - & $2.6212 \mathrm{H}$ & $5.582 \mathrm{H}$ \\
{$\left[\mathrm{MoO}_{2}\left(\mathrm{ML}^{4}\right)\right](\mathrm{acac})_{2}$} & $6.8710 \mathrm{H}$ & - & $2.5412 \mathrm{H}$ & $5.702 \mathrm{H}$ \\
\hline
\end{tabular}

\section{UV-Visible spectra}

The Ultraviolet-Vis spectra of tetradentate tetraaza ligand and the dixomolybdenum(VI) complexes were recorded in ethanol and these spectral bands are measured according to reported energy level scheme ${ }^{49,50}$. The spectra of the dixomolybdenum(VI) complexes with tetradentate ligand are similar as one another thereby suggesting a standard structure for all. Since $\mathrm{Mo}(\mathrm{VI})$ ion has no $d$-electron, the absorption bands of pure $\mathrm{d}$-d origins do not seem to be expected to appear. The bands for all complexes may perhaps to be appointed as charge transfer transition from nitrogen orbital to a molybdenum metal d-orbital $[\mathrm{N}(\pi) \rightarrow d(\mathrm{Mo})]$. The ultraviolet-vis spectra are similar to other complexes of dioxomolybdenum(VI) having nitrogen donor atoms. The ultraviolet-vis spectra of these complexes are characterized by strong absorption bands within the UV region at $\approx 290 \mathrm{~nm}$ and at $\approx 333 \mathrm{~nm}$ seem to be due to intraligand transition and $\mathrm{n} \rightarrow \pi^{*} / \pi \rightarrow \pi^{*}$ transitions. A moderately intense band appeared within the region $\approx 385 \mathrm{~nm}-390 \mathrm{~nm}$ is attributed to $\mathrm{N}(\pi) \rightarrow d(\mathrm{Mo})$. The band because of the transition ${ }^{2} B_{2} \rightarrow{ }^{2} A_{l}\left(d_{x y} \rightarrow d_{x 2-y 2}\right)$ is maybe covert by the above bands and should be appointed for $\mathrm{L} \rightarrow \mathrm{M}$ charge - transfer transition between the lowest unoccupied molybdenum $d$-orbital and highest occupied ligand molecular orbital ${ }^{51,52}$. Ballhausen - Gray energy level scheme have provided energy level scheme for these complexes. The electronic spectra designate a distorted octahedral geometry for all the complexes ${ }^{53}$.

\section{Magnetic and molar conductance measurements}

The dioxomolybdenum(VI) complexes are diamagnetic, as needless to say for $\mathrm{d}^{0}$ configuration. Since there is no electron present in d-orbital, no d-d transitions are determined for these complexes. The molar conductivity $(\Lambda \mathrm{M})$ values for all dioxomolybdenum(VI) complexes in DMF at ca. $10^{-3} \mathrm{M}$ recommend 1:1 sort electrolytes. The molar conductance values of those complexes lie between $95-110 \Omega^{-1} \mathrm{~cm}^{2} \mathrm{~mol}^{-1}$. In last, the on top molar conductance values support the tentative structures of dioxomolybdenum(VI) complexes of the type I and macrocyclic complexes of the type II as shown within the schemes.

\section{Thermogravimetric analyses}

The thermogravimetric examination of $\left[\mathrm{MoO}_{2}(\mathrm{~L})\right](\mathrm{acac})_{2}$ complex was directed in the temperature range $50-600{ }^{\circ} \mathrm{C}$ with a $10{ }^{\circ} \mathrm{C} \mathrm{min}^{-1}$ temperature interim. No transparent decomposition observed beneath $145^{\circ} \mathrm{C}$ (Figure 1). The thermograph of the $\left[\mathrm{MoO}_{2}(\mathrm{~L})\right](\mathrm{acac})_{2}$ 
complex is appeared in Figure 1. The $\left[\mathrm{MoO}_{2}(\mathrm{~L})\right](\mathrm{acac})_{2}$ complex undergoes decomposition in two stages: (a) first stage of decomposition $\left(145-250{ }^{\circ} \mathrm{C}\right.$ ) is due to the loss of ligand (mass loss obs. $45 \%$, calcd. $48 \%$ ) (b) in the second stage, the second progressive weight reduction of at raised temperature $\left(300-450{ }^{\circ} \mathrm{C}\right)$ giving a mass loss about $42 \%$ against calculated mass loss of $48 \%$. At last, a residue obtained generally compares to $\mathrm{MoO}_{3}$ (obs. Residual mass = $14.50 \%$, calcd. $=15.75 \%$ ) have been left after $450{ }^{\circ} \mathrm{C}$. Two vertexes were gotten in DTA curve. First vertex is endothermic decay because of melting of the complex $\left(145^{\circ} \mathrm{C}\right)$. The second vertex is due to the exothermic effect. Close to this exothermic vertex in DTA curve an exothermic hump was also observed at $435{ }^{\circ} \mathrm{C}$ which may because of exothermic decay of the leftover mass in the second step.

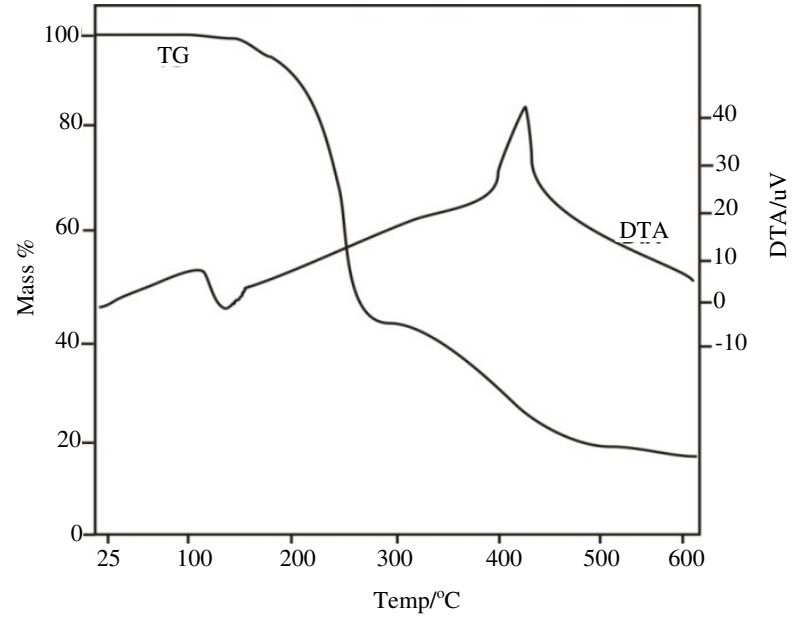

Figure 1. TG and DTA thermographs of $\left[\mathrm{MoO}_{2}(\mathrm{~L})\right](\mathrm{acac})_{2}$

\section{Antibacterial activity}

The results of the antimicrobial exercises of the synthesized dioxomolybdenum(VI) complexes are given in Table 5. The prepared dioxomolybdenum(VI) complexes were tried against Staphylococcus aureus, Bacillus subtilis, Enterobacter aerogenes and- Salmonella typhi. The upgrade in the antibacterial activity of dioxomolybdenum(VI) complexes can be clarified on the basis of chelation hypothesis ${ }^{47,48}$. The reference material is doxycycline medicine. Practically all the complexes indicated low to moderate activity against $S$. aureus and S. typhi.

Table 5. Antibacterial activities of macrocyclic complexes of dioxomolybdenum(VI)

\begin{tabular}{cccccc}
\hline Complex & $\begin{array}{c}\text { Staphylococcus } \\
\text { aureus }\end{array}$ & $\begin{array}{c}\text { Enterobacter } \\
\text { aerogenes }\end{array}$ & $\begin{array}{c}\text { Salmonella } \\
\text { typhi }\end{array}$ & $\begin{array}{c}\text { Bacillus } \\
\text { subtilis }\end{array}$ & Doxycycline \\
\hline$\left[\mathrm{MoO}_{2}(\mathrm{~L})\right](\mathrm{acac})_{2}$ & 15 & 15 & 18 & 21 & 25 \\
{$\left[\mathrm{MoO}_{2}\left(\mathrm{ML}^{1}\right)\right](\mathrm{acac})_{2}$} & 17 & 20 & 16 & - & 23 \\
{$\left[\mathrm{MoO}_{2}\left(\mathrm{ML}^{2}\right)\right](\mathrm{acac})_{2}$} & 16 & 19 & - & 17 & 25 \\
{$\left[\mathrm{MoO}_{2}\left(\mathrm{ML}^{3}\right)\right](\mathrm{acac})_{2}$} & 14 & 20 & 19 & 22 & 23 \\
{$\left[\mathrm{MoO}_{2}\left(\mathrm{ML}^{4}\right)\right](\mathrm{acac})_{2}$} & 14 & 17 & 17 & 20 & 26 \\
\hline
\end{tabular}

\section{Conclusion}

The present investigation exhibit basic synthetic paths to get new dioxomolybdenum(VI) with Schiff base. The utilized spectroscopic procedures have affirmed the Schiff base condensation 
of thenil which is a versatile chelating agent having two responsive carbonyl groups with diamines and their cyclizations with $\beta$-diketones undergoing formation of macrocyclic products to guarantee controlled geometry around $\mathrm{MoO}_{2}(\mathrm{VI})$ centre. The shape around Mo is distorted octahedral. The kinetic template effect of dioxomolybdenum(VI) cation assumes a significant role in the preparation of Schiff base using thenil and diamines in ethanol medium. Prepared Schiff bases act as tetradentate ligands by coordinating to the metal ion through the azomethine nitrogen atoms. The existence of one metal ion per ligand molecule is affirmed by analytical data. The mononuclear six coordination of all the synthesized cis-dioxomolybdenum(VI) complexes, and the six coordinate distorted octahedral structure have been proposed for these complexes. X-ray crystallographic data, which may affirm the tentative structures, couldn't be possible, as appropriate crystals were not isolated.

\section{Acknowledgment}

The authors might want to thank the Secretary, Board of Management, D.A-V. P.G. College, Kanpur, U.P., India for providing laboratory facilities to look into work. Analytical facilities provided by IIT Kanpur and UPTTI Kanpur India are thankfully recognized.

\section{References}

1. Healy M D S and Rest A J, Advances Inorg Chem Radiochem., 1978, 21, 1-40; DOI:10.1016/S0065-2792(08)60277-0

2. Melson G A, Coordination Chemistry of Macrocyclic Compounds, New York, 1979.

3. Lindoy L F and Busch D H, Prep Inorg React., 1971, 6, 1.

4. Lindoy L F and Busch D H, Inorg Chem., 1974, 13(10), 2494-2498; DOI:10.1021/ic50140a037

5. Yadav H D S, Sengupta S K and Tripathi S C, Inorg Chim Acta, 1987, 128(1), 1-6; DOI:10.1016/S0020-1693(00)84685-X

6. Crans D C, Pure Appl Chem., 2005, 77, 1407-1527.

7. Bagherzadeh M, Latifi R, Tahsini L, Amani V, Ellern A and Woo L K, Polyhedron, 2009, 28, 2517-2521; DOI:10.1016/j.poly.2009.05.036

8. Moradi-Shoeili Z, Zare M, Bagherzadeh M, Kubicki M and Boghaei D M, J Coord Chem., 2015, 68(2), 548-559; DOI:10.1080/00958972.2014.978308

9. Bagherzadeh M, Amini M and Parastar H, Inorg Chem Commun., 2012, 20, 86-89; DOI:10.1016/j.inoche.2012.02.023

10. Aziz A A A, J Mol Struct., 2010, 979(1-3), 77-85; DOI:10.1016/j.molstruc.2010.06.004

11. Chakravarthy R D, Suresh K, Ramkumar V and Chand D K, Inorg Chim Acta, 2011, 376(1), 57-63; DOI:10.1016/j.ica.2011.05.033

12. Rayati S, Rafiee N and Wojtczak A, Inorg Chim Acta, 2015, 386, 27-35; DOI:10.1016/j.ica.2012.02.005

13. Pushie M J and George G N, Coord Chem Rev., 2011, 255(9-10), 1055-1084; DOI:10.1016/j.ccr.2011.01.056

14. Rao C P, Sreedhara A, Rao P V, Verghese M B, Rissanen K, Kolehmainen E, Lokanath N K, Sridhar M A and Prasad J S, J Chem Soc., 1998, 14, 2383-2394; DOI:10.1039/A801226A

15. Hahn R, Herrmann W A, Artens G R J and Kleine M, Polyhedron, 1995, 14(20-21), 2953-2960; DOI:10.1016/0277-5387(95)00133-D

16. Mendel R R and Bittner F, Biochimica et Biophysica Acta-Molecular Cell Research, 2006, 1763, 621-635. 
17. Sigel A and Sigel H, Metal Ions in Biological Systems, Molybdenum and Tungsten: Their Roles in Biological Processes, Marcel Dekker, NY, 2002, 39.

18. Maurya RC, Shukla B and Pandey A, Indian J Chem., 2002, 41A, 554-559.

19. Rousso L, Friedman N, Sheves M and Ottolenghi M, Biochemistry, 1995, 34, 1205912065; DOI:10.1021/bi00037a049

20. Bassov $\mathrm{T}$ and Sheves M, Biochemistry, 1980, 25(18), 5249-5258; DOI:10.1021/bi00366a040

21. Mimoum H, Roch I S D and Sajus L, Tetrahedron, 1970, 26(1), 37-50; DOI:10.1016/0040-4020(70)85005-0

22. Conte V and Furia F D, Catalytic Oxidations with Hydrogen Peroxide as Oxidant. Kluwer Academic Publisher, Berlin, 1992.

23. Mimoum H, Saussine L, Daire E, Postel M, Fisher J and Weiss R, J Am Chem Soc., 1983, 105(10), 3101-3110; DOI:10.1021/ja00348a025

24. Nair M L H and Thankamani D, Indian J Chem., 2009, 48A, 1212-1218.

25. Garner G D, Molybdenum, special topics in Comprehensive Coordination Chemistry, Wilkinson G, Ed., Pergamon press, Oxford, 1987, 6, 1421.

26. Niasari M S, Davar F and Bazarganipour M, Dalton Transactions, 2010, 39, 73307337; DOI:10.1039/B923416K

27. Ambroziak K, Mbeleck R, He Y, Saha B and Sherrington D C, Ind Eng Chem Res., 2009, 48, 3293-3302.

28. Vogel AI, A Text Book of Quantitative Inorganic Analysis, $4^{\text {th }}$ Edn., Longmans Green Co. Ltd., London, 1978.

29. Vogel AI, A Text book of Practical Organic Chemistry, $4^{\text {th }}$ Edn., Longmans Green Co. Ltd., London, 1978.

30. Rana V B, Singh P, Singh D P and Teotia M P, Transition Met Chem., 1982, 7(3), 174-177; DOI:10.1007/BF01035836

31. Chandra S and Sharma K K, Transition Met Chem., 1983, 8(1), 1-3; DOI:10.1007/BF00618784

32. Malik W U, Bembi R and Singh R, Inorg Chim Acta, 1983, 68, 223-228; DOI:10.1016/S0020-1693(00)88965-3

33. Owaik T G, Sobczak L J J M and Kowski J J Z, Inorg Chim Acta, 2003, 356(3), 387 392; DOI:10.1016/S0020-1693(03)00301-3

34. Ferraro J R, Low Frequency Vibrations of Inorganic and Coordination Compounds, Plenum, New York, 1971.

36. Dyer J R, Applications of absorption spectroscopy of organic compounds, PrenticeHall, Inc., Englewood Cliffs, NJ, 1965.

36. Singh S, Rao D P, Yadava A K and Yadav H S, Current Res Chem., 2011, 3(2), 106113; DOI:10.3923/crc.2011.106.113

37. Willis L J, Loehr T M, Miller K F, Bruce A E and Stiefe E I, Inorg Chem., 1986, 25(23), 4289-4293; DOI:10.1021/ic00243a045

38. Ceylan B I, Kurt Y D and Ulkuseven B, J Coord Chem., 2009, 62(5), 757-766; DOI:10.1080/00958970802339669

39. Rao S N, Munshi K N, Rao N N, Bhadbhade M M and Suresh E, Polyhedron, 1999, 18(19), 2491-2497; DOI:10.1016/S0277-5387(99)00139-4

40. El-Medani S M, Aboaly M M, Abdalla H H and Ramadan R M, Spectrosc Lett., 2004, 37(6), 619-632; DOI:10.1081/SL-200037610

41. Zhu X W, Acta Chim Slov., 2018, 65, 939-945; DOI:10.17344/acsi.2018.4607 
42. Maurya R C, Verma R and Singh T, Synth React Inorg Met-Org Chem., 2003, 33(2), 309-325; DOI:10.1081/SIM-120017789

43. Wang X, Zhang X M and Liu H X, J Coord Chem., 1994, 33, 223-228.

44. Rao D P, Yadav H S, Yadava A K, Singh S and Yadav U S, J Chem., 2012, 9(2), 497 503; DOI:10.1155/2012/205123

45. Cotton F A, Wilkinson G, Murillo C A and Bochmann M, Advanced Inorganic Chemistry, $6^{\text {th }}$ Edn., Wiley, New York, 1994, 18, 944.

46. Nakamoto K, IR and Raman Spectra of Inorganic and Coordination Compounds, part A and B, John Wiley and Sons, New York, 1998.

47. Jr H G and Veal J, Inorg Chim Acta, 1969, 3, 623-627; DOI:10.1016/S00201693(00)92563-5

48. Yadav H S, Polyhedron, 1993, 12(3), 313-317; DOI:10.1016/S0277-5387(00)81729-5

49. Rao D P, Yadav H S, Yadava A K, Singh S and Yadav U S, J Coord Chem., 2011, 64(2), 293-299; DOI:10.1080/00958972.2010.544037

50. Sakata K, Kuroda M, Yanagida S and Hashimoto M, Inorg Chim Acta, 1989, 156(1), 107-112; DOI:10.1016/S0020-1693(00)90375-X

51. Garg R, Saini M K, Fahmi N and Singh R V, Transition Met Chem., 2006, 31(3), 362-367; DOI:10.1007/s11243-005-0001-1

52. Kahroic E, Molcano K, Tusek-Bozic L and Kojic-Prodic B, Polyhedron, 2006, 25(12), 2459-2464; DOI:10.1016/j.poly.2006.02.008

53. Ballhausen $\mathrm{C} \mathrm{J}$ and Gray H B, Inorg Chem., 1962, 1(1), 111-122; DOI:10.1021/ic50001a022 